\title{
Characterization of Chemically Activated Carbons Prepared from Miscanthus and Switchgrass Biomass
}

\author{
Beata Doczekalska ${ }^{1, *}$, Monika Bartkowiak ${ }^{1}$, Bogusława Waliszewska ${ }^{1}$, Grażyna Orszulak ${ }^{1}$, \\ Joanna Cerazy-Waliszewska ${ }^{2}$ and Tomasz Pniewski ${ }^{2, *(D)}$ \\ 1 Institute of Chemical Wood Technology, Poznań University of Life Sciences, Wojska Polskiego 38/42, \\ 60-637 Poznań, Poland; monika.bartkowiak@up.poznan.pl (M.B.); bwaliszewska@up.poznan.pl (B.W.); \\ grazyna.orszulak@gmail.com (G.O.) \\ 2 Institute of Plant Genetics of the Polish Academic of Sciences, Strzeszyńska 34, 60-479 Poznań, Poland; \\ jcer@igr.poznan.pl \\ * Correspondence: beata.doczekalska@up.poznan.pl (B.D.); tpni@igr.poznan.pl (T.P.)
}

Received: 5 February 2020; Accepted: 31 March 2020; Published: 2 April 2020

check for updates

\begin{abstract}
Lignocellulosic biomass, including that of energy crops, can be an alternative source to produce activated carbons (ACs). Miscanthus and switchgrass straw were used to produce ACs in a two-step process. Crushed plant material was carbonized at $600^{\circ} \mathrm{C}$ and then obtained carbon was activated using $\mathrm{NaOH}$ or $\mathrm{KOH}$ at $750^{\circ} \mathrm{C}$. The content of surface oxygen groups was determined using Boehm's method. The porosity of ACs was assayed using the nitrogen adsorption/desorption technique, while their thermal resistance using the thermogravimetric method. The ACs derived from miscanthus and switchgrass were characterized by surfaces rich in chemical groups and a highly developed porous structure. The highest specific surface areas, over $1600 \mathrm{~m}^{2} / \mathrm{g}$, were obtained after carbon treatment with $\mathrm{NaOH}$. High values of iodine number, $1200-1240 \mathrm{mg} / \mathrm{g}$, indicate an extensive system of micropores and their good adsorption properties. The type of activator affected the contents of oxygen functional groups and some porosity parameters as well as thermal stability ranges of the ACs. Among obtained carbons, the highest quality was found for these derived from $M$. sacchariflorus followed by switchgrass, after activation with $\mathrm{NaOH}$. Hence, while these crop species are not as effective biomass sources as other energy grasses, they can become valuable feedstocks for ACs.
\end{abstract}

Keywords: activated carbon; miscanthus; switchgrass; porosity

\section{Introduction}

Since the moment activated carbon (AC) was obtained for the first time in 1900 by Raphael Von Ostrejko, considered to be the "father of activated carbon", the demand for this product has been permanently growing [1]. The market for AC is expected to register a Compound Annual Growth Rate of $6.31 \%$ during the forecast period of 2019-2024. Major factors driving the market studied include conformance to stringent environmental regulations in water treatment applications and increasing the importance of air pollution control, especially mercury removal [2]. Thanks to its high adsorption capacity and large surface area, AC dominates on the global adsorbent market, accounting for over $65 \%$ of the market trade volume [3]. AC has become the preferred option for use in potable water purification, treatment of aquariums, swimming pools and wastewater as well as air and gas filtration. These applications are the most important due to increasing environmental pollution, health concerns and stringent government regulations [4]. Apart from that, AC is used in the food industry for the decolorization and deodorization of food and beverages, and in the pharmaceutical industry for the purification of vitamins, antibiotics and other compounds [5]. Other applications of activated carbon include monitoring gas emissions in automobiles, personal protection in the defense sector, recovery of 
gold and precious metals and as a catalyst in the removal of mercaptans in oil refineries [6,7]. ACs are also increasingly popular in electrochemistry, for energy storage and production of capacitors and Li-ion batteries [8,9].

The AC market is currently facing price issues due to the shortage of resources and increasing concerns concerning the supply chain. However, the market is on the rise due to the extensive use of $\mathrm{AC}$ in applications for the liquid and gas phase [3]. Carbon porous materials may be obtained from many fossil and organic feedstocks. Initially, coal, lignite, crude oil and wood were most frequently used for the production of porous materials. Over time, the activated carbon industry was forced to look for alternative precursors that would be cheaper and meet environmental requirements in view of increased costs of traditional feedstocks and severe fines for environmental pollution. Lignocellulosic biomass has proved to be an attractive solution to these problems from both economic and ecological points of view. Many types of agricultural and forestry waste materials as straw, fruit stones, shells of walnuts, pistachios and coconuts, cones, branches and carps, as well as seaweed, have been exploited to produce ACs $[10,11]$. Thanks to carbonization and activation, these wastes can be converted into valuable porous materials instead of undergoing gradual degradation and useless loss [11,12].

Nevertheless, energy crops have been investigated for several years as an alternative feedstock for carbonization. Thanks to the fast and abundant biomass production, they represent a considerable resource. Such grasses as particularly miscanthus species (Miscanthus spp.) or switchgrass (Panicum virgatum) may provide demanded amounts of raw material thanks to their adaptability to various environments, especially in countries of temperate climate [13-15]. Depending on the species and local cultivation conditions, the biomass production for miscanthus ranges from 9.0 to $30 \mathrm{t} / \mathrm{ha}$, the lowest being for $M$. sacchariflorus and the highest for $M . \times$ giganteus, while the yield range for switchgrass is 6-20 $t / h a$ [16-19]. The global cultivation area of these crops may be easily expanded, since these grasses are able to grow on marginal lands [20-22]. In fact, miscanthus and switchgrass biomass have already been grown to produce biochar of potential use for soil and groundwater remediation or improvement [23-26]. However, making ACs for industrial or medicinal and other applications requires additional processing of crude carbonizate and the evaluation of obtained products. So far, relatively few studies have been conducted on the subject regarding $M . \times$ giganteus $[9,27]$.

The objective of this study was to prepare activated carbons from the biomass of energy grasses, Miscanthus $\times$ giganteus, $M$. sinensis, $M$. sacchariflorus and Panicum virgatum, and evaluate their porosity. Crude carbonizates were activated chemically using $\mathrm{KOH}$ and $\mathrm{NaOH}$. Physical and chemical properties of the obtained activated carbons, including surface chemical groups, porosity parameters and thermal stability, were characterized.

\section{Materials and Methods}

\subsection{Plant Materials}

All genotypes of miscanthus (Miscanthus spp.) and switchgrass (Panicum virgatum) used as the feedstock in the study were received from the collection of TINPLANT GmbH (Klein Wanzleben, Germany). Miscanthus $\times$ giganteus was represented by the $\mathrm{M} \times \mathrm{g} 3$ ecotype, i.e., genotype M116-a synthetic hybrid obtained by TINPLANT GmbH - and then cultivated for several seasons at the Novosibirsk State Agriculture University (Russia). In turn, M. sinensis was represented by genotype 93M0006004 of Japanese origin, while $M$. sacchariflorus was represented by the Chinese diploid genotype 96M0003. Switchgrass was represented by the diploid genotype Kanlow. All miscanthus plants were obtained from rhizomes, while switchgrass from seeds. The plants have been cultivated since 2009 on medium-fertile Orthic Luvisol soil (FAO classification) in the field located at the Institute of Plant Genetics, Polish Academy of Sciences (IPG PAS) in Poznań (52 $25^{\prime} \mathrm{N}, 16^{\circ} 55^{\prime}$ E) [19]. No fertilizers were applied during the entire cultivation period. Weather conditions were typical of west-central Poland [28], characterized by locally low precipitation (500-600 mm yearly). For the study, plant biomass was harvested in winter 2017, then chopped and stored in a cold and dry place until used. 


\subsection{Analysis of Biomass Composition}

Particular components of biomass (dry matter (DM)) were assayed according to the TAPPI standards, including: (a) cellulose by Seifert's method using an acetylacetone-dioxane mixture [29]; (b) holocellulose using sodium chlorite (TAPPI-T $9 \mathrm{wd}-75$ ); (c) pentosans by Tollens' method using phloroglucinol (TAPPI-T $233 \mathrm{~cm}-84$ ); (d) lignin by the TAPPI method using concentrated sulfuric acid (TAPPI-T 222 om-06); (e) substances soluble in organic solvents according to Soxhlet (TAPPI-T $204 \mathrm{~cm}-07$ ); (f) substances soluble in cold and hot water (TAPPI-T $207 \mathrm{om}-88$ ); (g) substances soluble in 1\% NaOH (TAPPI-T $212 \mathrm{om}-07$ ); and (h) ash (TAPPI-T $211 \mathrm{~cm}-86$ ). Hemicellulose theoretical content was calculated as the difference between holocellulose and cellulose.

\subsection{Preparation of Activated Carbon}

The lignocellulosic materials were ground using an SM100 mill (Retsch GmbH, Haan, Germany) equipped with a $0.5 \mathrm{~mm}$ sieve and next carbonized. This process was carried out in a chamber reactor in the oxygen-free atmosphere by heating to $600{ }^{\circ} \mathrm{C}$ at a rate of $3{ }^{\circ} \mathrm{C} / \mathrm{min}$ and then maintained under stable conditions for $1 \mathrm{~h}$. Carbonizates after grinding in mortar were activated with potassium or sodium hydroxide at the $1: 4$ ratio $(\mathrm{w} / \mathrm{w})$ in the argon atmosphere at $750{ }^{\circ} \mathrm{C}$ for $15 \mathrm{~min}$ in a non-porous ceramic reactor (Czylok, Jastrzębie-Zdrój, Poland). Activated carbons (ACs) were washed out with 1\% hydrochloric acid and then deionized water to the neutral $\mathrm{pH}$.

\subsection{Characterization of Activated Carbons}

Contents of surface oxygen groups ( $\mathrm{mmol} / \mathrm{g}$ ) were determined according to Boehm's method [30]. Briefly, 4 samples of activated carbon, $250 \mathrm{mg}$ each, were placed separately in $250 \mathrm{~mL}$ flasks. Then, each sample was supplemented with $25 \mathrm{~mL}$ of $0.1 \mathrm{M} \mathrm{NaOH}, 0.1 \mathrm{M} \mathrm{NaHCO}_{3}$ or $0.05 \mathrm{M} \mathrm{Na}_{2} \mathrm{CO}_{3}$ (to assay acidic groups) or $0.1 \mathrm{M} \mathrm{HCl}$ (to assay basic groups), and the mixtures were shaken at $\sim 120 \mathrm{rpm}$ for $24 \mathrm{~h}$ at room temperature. After filtering the mixtures, $10 \mathrm{~mL}$ of each filtrate was pipetted and the excess of bases and acids was titrated (Tashiro indicator) using $0.1 \mathrm{M} \mathrm{HCl}$ or $\mathrm{NaOH}$, respectively. All assays were repeated three times. Numbers of acidic sites of various types were calculated according to the formula below under the assumption that $\mathrm{NaOH}$ neutralizes carboxyl, phenolic and lactonic groups: $\mathrm{Na}_{2} \mathrm{CO}_{3}$, carboxyl and lactonic ones, and $\mathrm{NaHCO}_{3}$, only carboxyl groups. The number of surface basic sites was calculated according to the same formula, but this time from the amount of $\mathrm{HCl}$ which reacted with carbon.

$$
G_{x}=\left(V_{0}-V_{x}\right) \times c \times \frac{25}{W_{x}}\left[\frac{\mathrm{mmol}}{\mathrm{g}}\right]
$$

where:

$G_{x}$-content of functional groups of a given type;

$V_{0}, V_{x}$-volumes of $\mathrm{NaOH}$ or $\mathrm{HCl}$ solutions (for assays of acidic or basic groups, respectively) used for titration of assayed $\left(V_{x}\right)$ and blank samples $\left(V_{0}\right)(\mathrm{mL})$;

$c-\mathrm{HCl}$ or $\mathrm{NaOH}$ concentration $(\mathrm{M})$;

$W_{x}$-weight of carbonizate sample (g).

The specific surface area and pore size distribution were determined by analysis of nitrogen adsorption at $-196^{\circ} \mathrm{C}$ (ASAPтM2020, Micromeritics Instrument Corp., Norcross, GA, USA). Samples before measurement were degassed at $300^{\circ} \mathrm{C}$ for $10 \mathrm{~h}$ at a pressure of $10^{-6} \mathrm{~Pa}$. Collected sorption data facilitated calculation of the following structural parameters in the area of micro- and mesopores:

$\mathrm{S}_{\mathrm{BET}}$-specific surface area $\left(\mathrm{m}^{2} / \mathrm{g}\right)$ - by the BET method, to the relative pressure $\mathrm{p} / \mathrm{p}_{0} \approx 0.2$;

$\mathrm{V}_{\mathrm{T}}$-a total pore volume $\left(\mathrm{cm}^{3} / \mathrm{g}\right)$-determined from the isotherm at a relative pressure $\mathrm{p} / \mathrm{p}_{0} \approx 0.975 ;$

$\mathrm{V}_{\text {meso }}$-mesopore volume by the BJH method $\left(\mathrm{cm}^{3} / \mathrm{g}\right)$;

$\mathrm{V}_{\text {micro }}-$ micropore volume from differences $\mathrm{V}_{\mathrm{T}}-\mathrm{V}_{\text {meso }}\left(\mathrm{cm}^{3} / \mathrm{g}\right)$;

$d_{a v}$-average pore diameter calculated using the formula $d_{a v}=4 V_{T} / S_{B E T}(n m)$. 
Iodine numbers (IN) of activated carbons were determined on the basis of the Standard Test Method ASTM Designation: D 1510-57 T ASTM-D4607-94. Thus, iodine number ( $\mathrm{mg} \mathrm{I}_{2} / \mathrm{g}$ carbon) was measured by titration at $30^{\circ} \mathrm{C}$. This parameter indicated the extent of micropore distribution in activated carbon and allowed evaluating its adsorption capacity. From each activated carbon, three dried samples $(0.1 \mathrm{~g})$ were placed into separated flasks and fully wetted with $10 \mathrm{~mL}$ of $5 \% \mathrm{HCl}$. Then $100 \mathrm{~mL}$ of $0.025 \mathrm{M}$ standard iodine solution was poured into the flask and the content was vigorously shaken for $30 \mathrm{~s}$. After quick filtration, $50 \mathrm{~mL}$ of the solution was titrated using $0.1 \mathrm{M}$ sodium thiosulfate with starch as an indicator. The concentration of iodine in the solution was calculated according to the formula below from the total volume of sodium thiosulfate used.

$$
\mathrm{IN}=\frac{\left(V_{0}-V_{x}\right) \times c_{\text {thio }} \times 126.92}{m}\left[\frac{\mathrm{mg}}{\mathrm{g}}\right]
$$

where:

$V_{0}, V_{x}$-volumes of sodium thiosulfate solution used for titration of assayed $\left(V_{x}\right)$ and blank samples $\left(V_{0}\right)(\mathrm{mL})$

$c_{\text {thio }}$-concentration of sodium thiosulfate solution (M);

$m$-activated carbon sample (g);

126.92-mass of 1 mole of iodine (g).

Thermogravimetric (TG) analysis of activated carbons was carried out on a LabsysTM thermobalance (Setaram Instrumentation, Caluire, France) under the following conditions: final temperature $1200{ }^{\circ} \mathrm{C}$, rate of temperature increase at $5{ }^{\circ} \mathrm{C} / \mathrm{min}$ and helium atmosphere at the flowing rate of about $2 \mathrm{dm}^{3} / \mathrm{h}$. Mass loss of a sample was calculated in $\%$.

In order to facilitate the identification of activated carbons, the sample description system was adopted as shown in Table 1.

Table 1. Lignocellulosic materials and derived activated carbons obtained in the study.

\begin{tabular}{ccc}
\hline Lignocellulosic Material & Abbreviation & Activated Carbons \\
\hline M. $\times$ giganteus & MG & MG/KOH, MG/NaOH \\
M. sacchariflorus & MSac & Msac/KOH, MSac/NaOH \\
M. sinensis & MSin & MSin/KOH, MSin/NaOH \\
P. virgatum-switchgrass & SG & SG/KOH, SG/NaOH \\
\hline
\end{tabular}

\subsection{Statistical Analysis}

Obtained data were analyzed by two-way ANOVA (biomass composition, content of surface oxygen functional groups in activated carbons) followed by the post-hoc Tukey's test or one-way ANOVA (parameters of the porous structure and thermal stability of ACs). Statistical analysis was performed using the Statistica 13.0 statistical software package (StatSoft Inc, Tulsa, OK, USA).

\section{Results}

The chemical composition of biomass, as the feedstock to produce activated carbon, was assayed first (Tables 2 and 3). The content of holocellulose, comprising all carbohydrate components, was almost identical in biomass of individual miscanthus species, while that for switchgrass was significantly lower. Correspondingly, the content of cellulose, the major part of holocellulose, was similar in all three miscanthus species, while it was significantly higher than in switchgrass. In contrast to cellulose, the contents of hemicellulose and its predominant part, i.e., pentosans, did not differ between miscanthus species and switchgrass. In comparison to the observable tendencies in polysaccharide contents, that for lignin did not reflect biological classification. Significantly the most lignified was biomass of MG, followed by MSac and SG, whereas MSin was characterized by the lowest extent 
of lignification. However, the cellulose-lignin ratio only partially corresponded to lignin content. The highest ratio was recorded for MSin, medium for MSac, while it was the lowest for MG and SG (Table 2).

Table 2. Contents of main components of studied lignocellulosic raw materials. Significant differences between materials are marked by letter indexes, separately for each component.

\begin{tabular}{ccccc}
\hline Content (\%) & MG & MSac & MSin & SG \\
\hline Holocellulose & $74.42^{\mathrm{b}}$ & $73.68^{\mathrm{b}}$ & $73.91^{\mathrm{b}}$ & $70.77^{\mathrm{a}}$ \\
Cellulose & $45.12^{\mathrm{b}}$ & $44.57^{\mathrm{b}}$ & $44.12^{\mathrm{b}}$ & $40.30^{\mathrm{a}}$ \\
Hemicellulose & $29.30^{\mathrm{a}}$ & $29.11^{\mathrm{a}}$ & $29.79^{\mathrm{a}}$ & $30.47^{\mathrm{a}}$ \\
Pentosans & $24.39^{\mathrm{a}}$ & $24.71^{\mathrm{a}}$ & $24.49^{\mathrm{a}}$ & $24.35^{\mathrm{a}}$ \\
Lignin & $22.21^{\mathrm{c}}$ & $20.34^{\mathrm{b}}$ & $19.52^{\mathrm{a}}$ & $20.09^{\mathrm{b}}$ \\
Cellulose-Lignin & $2.03^{\mathrm{a}}$ & $2.19^{\mathrm{b}}$ & $2.26^{\mathrm{c}}$ & $2.01^{\mathrm{a}}$ \\
\hline
\end{tabular}

Table 3. Contents of extractives and ash in miscanthus and switchgrass lignocellulosic raw materials. Significant differences among materials are marked by letter indexes, separately for each substance.

\begin{tabular}{|c|c|c|c|c|c|}
\hline & Substance $(\%)$ : & MG & MSac & MSin & SG \\
\hline \multirow{5}{*}{ 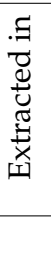 } & Cold water & $3.53^{b}$ & $2.61^{a}$ & $2.39^{a}$ & $7.12^{\mathrm{c}}$ \\
\hline & Hot water & $4.69^{\mathrm{a}}$ & $5.41^{b}$ & $4.99 \mathrm{ab}$ & $7.89^{c}$ \\
\hline & $1 \% \mathrm{NaOH}$ & $32.70^{\mathrm{a}}$ & $31.48^{\mathrm{a}}$ & $33.45^{b}$ & $34.44^{\mathrm{c}}$ \\
\hline & $\begin{array}{l}\text { Organic } \\
\text { solvents }\end{array}$ & $2.54^{\mathrm{a}}$ & $2.55^{\mathrm{a}}$ & $2.97^{a b}$ & $3.14^{\mathrm{c}}$ \\
\hline & Ash & $2.63^{b}$ & $2.16^{\mathrm{a}}$ & $2.54^{\mathrm{b}}$ & $2.20^{\mathrm{a}}$ \\
\hline
\end{tabular}

Contents of all categories of extractives were significantly higher in switchgrass in comparison to miscanthus. This discrepancy was particularly evident for substances soluble in cold or hot water. However, some differentiation was also observed among the miscanthus species. Except for substances soluble in cold water, contents of the other components in the MG biomass were closer to the lower limit of the range. Generally, MSin contained more extractives, while their levels in MSac varied, depending on the category. In turn, ash content was significantly lower in MSac and SG compared to MG and MSin (Table 3).

Despite the differentiation of biomass chemical composition, its impact on the physicochemical properties of activated carbons was secondary in comparison to an activator (Tables 4-6). Regardless of the type of precursor and hydroxide used at the activation temperature of $750{ }^{\circ} \mathrm{C}$, significantly more acidic groups were formed, 1.1-2.6 times compared to basic groups (Table 4). The former ones constituted approx. $70 \%$ in the case of $\mathrm{KOH}$ activation and approx. $60 \%$ in the case of $\mathrm{NaOH}$ activation, and this advantage was significant in both cases. Phenolic groups had the largest share in the total acidity of the surface and only for this category the effect of the activator was not evident and was partially modified by the precursor. However, in the case of lactonic and carboxyl groups, for all precursors, their content was significantly higher when $\mathrm{KOH}$ was used as an activator. The change of an activator from $\mathrm{KOH}$ to $\mathrm{NaOH}$ caused a significant increase in the number of basic oxygen groups, regardless of the type of precursor.

Similarly to the chemical nature of the surface, the effect of an activator was also evident regarding parameters of porosity, whereas the type of precursor was less important (Table 5). Specific surface area and volume of micro- and mesopores in produced ACs were calculated on the basis of sorption data from nitrogen adsorption/desorption isotherms at $-196{ }^{\circ} \mathrm{C}$ (Figure 1).

According to the IUPAC classification, the isotherms of nitrogen adsorption-desorption in analyzed ACs were of type I. Steep sorption curves in the range of very low relative pressures $\left(\mathrm{p} / \mathrm{p}_{0}<0.1\right)$ up to nitrogen sorption volumes close to $400 \mathrm{~cm}^{3} / \mathrm{g}$ STP indicated a well-developed system of micropores. All obtained ACs were characterized by extensive specific surface areas and large total pore volume. However, 
evidently higher $S_{B E T}$ values and larger volumes of micropores were obtained for ACs activated with the use of $\mathrm{NaOH}$, where the effect of activator was significant. The $\mathrm{V}_{\mathrm{T}}$ values were also higher for most $\mathrm{ACs}$ obtained by $\mathrm{NaOH}$ activation, yet here, this effect was statistically non-significant. The mesopore volumes differed among ACs activated with $\mathrm{NaOH}$, while they were almost identical in the case of $\mathrm{KOH}$. Low variability was also found for values of pore width and IN, although for most precursors they were slightly higher for ACs obtained by $\mathrm{NaOH}$ activation compared to $\mathrm{KOH}$. In summary, it can be said that the most developed porous structure, especially regarding such parameters as $\mathrm{S}_{\mathrm{BET}}, \mathrm{V}_{\text {micro }}$ and $\mathrm{V}_{\text {meso }}$, and IN, was found in ACs MSac/ $\mathrm{NaOH}$, followed by SG/NaOH (Table 5).

The results of TG analysis (Table 6) indicate varied thermal properties of the obtained carbon materials. However, analogously to the surface chemical groups and parameters of a porous structure, activators also had a greater effect than precursors, as indicated by respective $\mathrm{p}$-values for particular temperature ranges. The effect of activator was especially evident for the temperatures from 500 to $900{ }^{\circ} \mathrm{C}$, where it was statistically significant (Table 6). Relative mass losses demonstrated that ACs obtained by $\mathrm{NaOH}$ activation were more stable, except for the highest temperatures only. Nonetheless, the total mass losses determined for the whole measurement range $\left(20-1200{ }^{\circ} \mathrm{C}\right)$ showed comparable thermal stability of ACs in respect of an activator. All in all, the ACs MG/NaOH, MSin/ $\mathrm{NaOH}$ and $\mathrm{MSac} / \mathrm{KOH}$ may be considered the most thermally resistant.

Table 4. Contents of surface oxygen functional groups in activated carbons derived from miscanthus and switchgrass biomass. Significant differences between activated carbons (ACs) are marked by letter indexes, separately for each group (in columns). Significant differences between concentrations of total acidic vs. basic groups for a given AC are indicated by asterisk (in respective rows).

\begin{tabular}{cccccc}
\hline \multirow{2}{*}{ AC } & \multicolumn{5}{c}{ Functional Groups (mmol/g) } \\
& Carboxylic & $\begin{array}{c}\text { Acidic } \\
\text { Lactonic }\end{array}$ & Phenolic & Acidic (Total) & Basic (Total) \\
\hline $\mathrm{MG} / \mathrm{KOH}$ & $0.25^{\mathrm{d}}$ & $0.39^{\mathrm{b}}$ & $0.96^{\mathrm{e}}$ & ${ }^{*} 1.60^{\mathrm{e}}$ & $0.67^{\mathrm{b}}$ \\
$\mathrm{MSac} / \mathrm{KOH}$ & $0.29^{\mathrm{d}}$ & $0.49^{\mathrm{c}}$ & $0.71^{\mathrm{bc}}$ & ${ }^{*} 1.49^{\mathrm{d}}$ & $0.68^{\mathrm{b}}$ \\
$\mathrm{MSin} / \mathrm{KOH}$ & $0.30^{\mathrm{d}}$ & $0.49^{\mathrm{c}}$ & $0.72^{\mathrm{c}}$ & ${ }^{*} 1.51^{\mathrm{d}}$ & $0.58^{\mathrm{a}}$ \\
$\mathrm{SG} / \mathrm{KOH}$ & $0.25^{\mathrm{d}}$ & $0.45^{\mathrm{c}}$ & $0.90^{\mathrm{de}}$ & ${ }^{*} 1.60^{\mathrm{e}}$ & $0.75^{\mathrm{c}}$ \\
\hline $\mathrm{MG} / \mathrm{NaOH}$ & $0.19^{\mathrm{c}}$ & $0.35^{\mathrm{b}}$ & $0.64^{\mathrm{b}}$ & ${ }^{*} 1.18^{\mathrm{b}}$ & $0.77^{\mathrm{c}}$ \\
$\mathrm{MSac} / \mathrm{NaOH}$ & $0.05^{\mathrm{a}}$ & $0.34^{\mathrm{b}}$ & $0.83^{\mathrm{d}}$ & ${ }^{*} 1.22^{\mathrm{bc}}$ & $0.82^{\mathrm{d}}$ \\
$\mathrm{MSin} / \mathrm{NaOH}$ & $0.15^{\mathrm{bc}}$ & $0.39^{\mathrm{b}}$ & $0.54^{\mathrm{a}}$ & ${ }^{*} 1.08^{\mathrm{a}}$ & $0.98^{\mathrm{e}}$ \\
$\mathrm{SG} / \mathrm{NaOH}$ & $0.10^{\mathrm{ab}}$ & $0.24^{\mathrm{a}}$ & $0.95^{\mathrm{e}}$ & $* 1.29^{\mathrm{c}}$ & $0.98^{\mathrm{e}}$ \\
\hline
\end{tabular}

Table 5. Parameters of the porous structure in activated carbons derived from miscanthus and switchgrass lignocellulosic biomass.

\begin{tabular}{|c|c|c|c|c|c|c|}
\hline \multirow{2}{*}{ AC } & \multirow{2}{*}{$\begin{array}{c}\text { Surface Area } \\
\left(\mathrm{m}^{2} / \mathrm{g}\right) \\
\mathrm{S}_{\mathrm{BET}}\end{array}$} & \multicolumn{3}{|c|}{ Pore Volume $\left(\mathrm{cm}^{3} / \mathrm{g}\right)$} & \multirow{2}{*}{$\begin{array}{c}\text { Pore } \\
\text { Width } \\
(\mathrm{nm}) \\
\mathrm{d}_{\mathrm{av}}\end{array}$} & \multirow{2}{*}{$\begin{array}{c}\text { Iodine Number } \\
(\mathrm{mg} / \mathrm{g}) \\
\text { IN }\end{array}$} \\
\hline & & $\mathbf{V}_{\mathrm{T}}$ & $V_{\text {micro }}$ & $V_{\text {meso }}$ & & \\
\hline $\mathrm{MG} / \mathrm{KOH}$ & 1542 & 1.05 & 0.53 & 0.52 & 2.72 & 1220 \\
\hline MSac/KOH & 1396 & 1.05 & 0.50 & 0.55 & 3.01 & 1230 \\
\hline $\mathrm{MSin} / \mathrm{KOH}$ & 1400 & 0.98 & 0.45 & 0.53 & 2.80 & 1200 \\
\hline SG/KOH & 1467 & 1.03 & 0.50 & 0.53 & 2.81 & 1210 \\
\hline MG/NaOH & 1689 & 1.08 & 0.59 & 0.49 & 2.56 & 1210 \\
\hline $\mathrm{MSac} / \mathrm{NaOH}$ & 1796 & 1.52 & 0.62 & 0.90 & 3.38 & 1240 \\
\hline $\mathrm{MSin} / \mathrm{NaOH}$ & 1612 & 0.95 & 0.63 & 0.32 & 2.36 & 1220 \\
\hline $\mathrm{SG} / \mathrm{NaOH}$ & 1731 & 1.24 & 0.61 & 0.63 & 2.86 & 1230 \\
\hline $\begin{array}{l}\text { p-value for } \\
\text { effect of } \\
\text { activator }\end{array}$ & $0.003 *$ & 0.219 & $\underset{*}{0.001}$ & 0.684 & 0.852 & 0.315 \\
\hline $\begin{array}{l}\mathrm{p} \text {-value for } \\
\text { effect of } \\
\text { precursor }\end{array}$ & 0.936 & 0.451 & 0.995 & 0.350 & 0.132 & 0.276 \\
\hline
\end{tabular}


Table 6. Thermogravimetric analysis of activated carbons derived from miscanthus and switchgrass lignocellulosic raw materials.

\begin{tabular}{|c|c|c|c|c|c|c|}
\hline \multirow{2}{*}{ ACs } & \multicolumn{6}{|c|}{ Mass Loss (\%) } \\
\hline & $20-200{ }^{\circ} \mathrm{C}$ & $200-500{ }^{\circ} \mathrm{C}$ & $500-700^{\circ} \mathrm{C}$ & $700-900{ }^{\circ} \mathrm{C}$ & $900-1200{ }^{\circ} \mathrm{C}$ & $20-1200^{\circ} \mathrm{C}$ \\
\hline $\mathrm{MG} / \mathrm{KOH}$ & 2.86 & 4.54 & 3.91 & 3.97 & 5.73 & 21.01 \\
\hline $\mathrm{MSac} / \mathrm{KOH}$ & 2.31 & 3.90 & 3.53 & 3.81 & 6.16 & 19.71 \\
\hline MSin/KOH & 2.52 & 4.80 & 4.39 & 4.19 & 7.25 & 23.15 \\
\hline $\mathrm{SG} / \mathrm{KOH}$ & 2.42 & 4.06 & 3.75 & 3.67 & 6.26 & 20.15 \\
\hline $\mathrm{MG} / \mathrm{NaOH}$ & 2.52 & 3.51 & 2.36 & 3.12 & 6.22 & 17.73 \\
\hline $\mathrm{MSac} / \mathrm{NaOH}$ & 2.27 & 3.12 & 1.99 & 3.43 & 13.38 & 24.20 \\
\hline $\mathrm{MSin} / \mathrm{NaOH}$ & 2.14 & 3.74 & 2.38 & 2.79 & 8.16 & 19.21 \\
\hline $\begin{array}{l}\mathrm{SG} / \mathrm{NaOH} \\
\mathrm{p} \text {-value for }\end{array}$ & 2.07 & 4.74 & 2.37 & 3.28 & 11.02 & 23.47 \\
\hline $\begin{array}{l}\text { effect of } \\
\text { activator }\end{array}$ & 0.123 & 0.224 & $<0.001 *$ & $0.005^{*}$ & 0.083 & 0.936 \\
\hline $\begin{array}{l}\text { p-value for } \\
\text { effect of } \\
\text { precursor }\end{array}$ & 0.298 & 0.573 & 0.957 & 0.994 & 0.678 & 0.766 \\
\hline
\end{tabular}

*-significant.

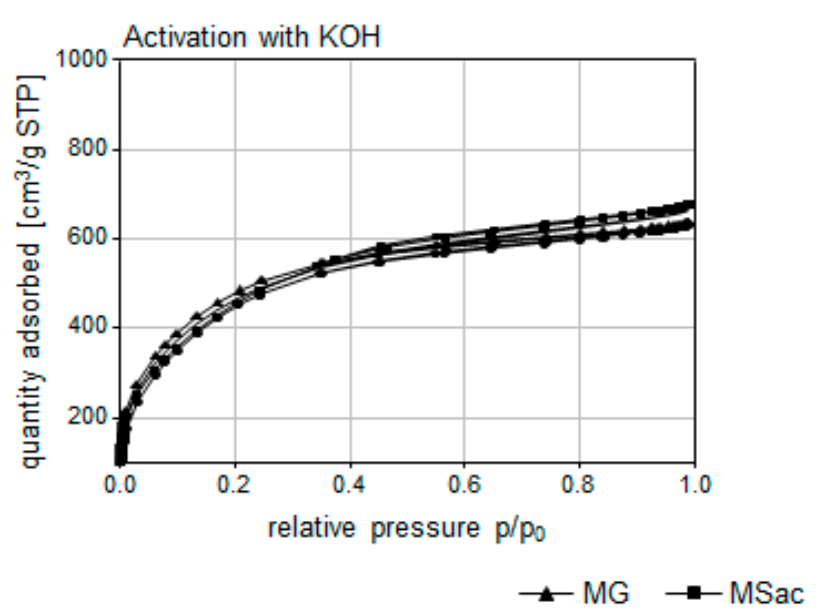

(a)

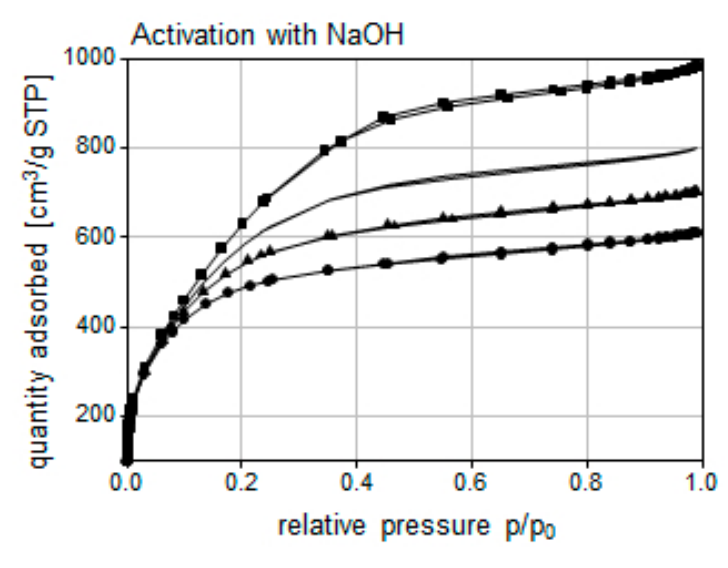

MSin - SG

(b)

Figure 1. Isotherms of $\mathrm{N}_{2}$ adsorption-desorption by ACs obtained from biomass of miscanthus species and switchgrass using $\mathrm{KOH}(\mathbf{a})$ or $\mathrm{NaOH}(\mathbf{b})$ as the activator.

\section{Discussion}

\subsection{Composition of Miscanthus and Switchgrass Biomass as a Feedstock for Carbonization}

Porous structure and other characteristics of activated carbon are determined by the properties of the feedstock and conditions of carbonization and activation. In turn, the chemical composition of biomass depends on many factors such as plant species, type of organ and tissue, growth conditions including climate, year of cultivation and harvesting time, etc. [31]. In the study, the winter-harvested biomass was used, as it is usually used for practical purposes and also contains higher levels of structural biopolymers, mainly holocellulose and lignin.

Here, holocellulose content in miscanthus corresponded with data recorded for plantations in the temperate climate zone $[19,32,33]$. Lower holocellulose contents in switchgrass biomass were also observed earlier $[34,35]$. Regarding cellulose, the main holocellulose component, the determined contents for $M . \times$ giganteus, $M$. sacchariflorus and $M$. sinensis (Table 2), also fell within the ranges for these species cultivated in other temperate regions [19,32,33,36,37]. In turn, Gismatulina and Budaeva [38] reported higher cellulose contents in biomass of $M$. sinensis, but cultivated under the severe continental 
climate of Siberia. In comparison to miscanthus, cellulose content in switchgrass was significantly lower (Table 2), which corresponds to data reported by other authors [18,33-35].

Unlike cellulose, the hemicellulose fraction in the tested raw materials did not differ significantly (Table 2). Yet, a slightly higher hemicellulose content was found in the species characterized by a lower cellulose fraction. Again, the observed amount of these low-polymerized carbohydrates corresponded with data reported for miscanthus and switchgrass cultivated in the temperate climate [32-37]. The content of pentosans corresponded to that for hemicellulose, as these glycans constitute a major fraction of the latter. Analogously, their content did not vary between the tested materials, similarly to an earlier report [19]. A larger discrepancy in the content of pentosans, between genotypes and also plant parts, was reported only for M. sinensis cultivated in the continental climate [38,39].

In contrast to hemicellulose, lignin content varied between the investigated grasses; yet this differentiation did not correspond to their genera as it was the case with cellulose. Biomass of $M . \times$ giganteus contained significantly the highest amount of lignin, while in the $M$. sinensis biomass it was the lowest (Table 2). This range of values is approx. 1.5-2 times higher in comparison to data from regions of maritime or warmer climates $[33,36,37]$, while it was similar to that for miscanthus or switchgrass cultivated under the continental climate $[19,33,35,38]$. Interestingly, the biomass of M. sacchariflorus and switchgrass, characterized by an intermediate lignin content, slightly above $20 \%$, after processing yielded ACs of the most developed porous structure (Table 5). However, this cannot be related to the cellulose-lignin ratio, as this parameter is determined by two other traits.

In contrast to structural cell wall biopolymers, switchgrass DM biomass, in comparison with miscanthus, contained more extractives, which include free sugars, proteins, dyes, waxes and other soluble compounds (Table 3). In particular, substances soluble in cold and hot water, were much more abundant, but the contents of other extractives were also significantly higher in switchgrass. Our results are comparable with data from previous reports, mostly regarding miscanthus and switchgrass coming from the transitional or continental climate $[19,32,34,36,38,40]$.

Compared to woody biomass, grasses are typically characterized by a higher content of ash, i.e., mineral compounds [41]. Low ash content (Table 3) in the tested miscanthus species was comparable to previously reported lower contents $(<3 \%)$ of mineral compounds in miscanthus biomass $[19,32,33,42]$. In the case of switchgrass, determined ash content can be classified as low in comparison to the reported $2.1 \%-8.8 \%[18,35]$. However, most authors reported higher ash contents, showing a considerable effect of growing conditions, including year of cultivation, location, type of soil or fertilization $[18,33,35,37-40,42-44]$. In this study, the biomass of $M$. sacchariflorus and switchgrass contained significantly lower amounts of ash than the other miscanthus species. It cannot be excluded that a low content of mineral compounds was reflected in the formation of a more developed porous structure in ACs (Table 5).

\subsection{Properties of Activated Carbons Derived from Miscanthus and Switchgrass Biomass}

The biomass of all tested energy grasses was carbonized at $600{ }^{\circ} \mathrm{C}$ according to the commonly adopted technique. All ACs derived from crude carbonizates were characterized by a rich chemical structure of the surface and substantial porosity (Tables 4 and 5). The effect of used activators, i.e., $\mathrm{KOH}$ or $\mathrm{NaOH}$, was much more evident than that of the precursor and it was statistically significant in the case of some AC parameters. Regardless of the type of precursor and hydroxide used, mainly acidic groups were generated (Table 4). They were predominantly phenolic groups, followed by lactonic and carboxyl groups. However, for all precursors, significantly more groups of the two latter types were identified on the surface of the carbons obtained after activation with $\mathrm{KOH}$. When $\mathrm{NaOH}$ was used as the activator, the number of basic oxygen groups significantly increased. Hence, based on the obtained results of the Boehm analysis, it may be concluded that the mechanisms of $\mathrm{KOH}$ and $\mathrm{NaOH}$ action on carbon precursors are not identical, which directly affects the surface structure of carbon materials.

The mechanisms of $\mathrm{KOH}$ and $\mathrm{NaOH}$ action on carbonizate precursors has been described (see chemical Equations (3)-(10) below) by many scientists [45-50]. It has been found that hydrogen 
is the product of the reaction for both these hydroxides with a carbon matrix (Equations (3) and (4), where Me is a potassium or sodium ion) [48,50]:

$$
\begin{gathered}
4 \mathrm{MeOH}+-\mathrm{CH}_{2} \rightarrow \mathrm{Me}_{2} \mathrm{CO}_{3}+\mathrm{Me}_{2} \mathrm{O}+3 \mathrm{H}_{2} \\
6 \mathrm{MeOH}+2 \mathrm{C} \rightarrow 2 \mathrm{Me}+3 \mathrm{H}_{2}+2 \mathrm{Me}_{2} \mathrm{CO}_{3}
\end{gathered}
$$

The reaction of the alkaline activator within the temperature range of $400-700^{\circ} \mathrm{C}$ leads to increased $\mathrm{CO}_{2}$ production (Equations (5) and (6)) [47,50]:

$$
\begin{gathered}
\mathrm{Me}_{2} \mathrm{CO}_{3} \rightarrow \mathrm{Me}_{2} \mathrm{O}+\mathrm{CO}_{2} \\
4 \mathrm{MeOH}+\mathrm{C} \rightarrow 4 \mathrm{Me}+\mathrm{CO}_{2}+\mathrm{H}_{2} \mathrm{O}
\end{gathered}
$$

During the heating of carbons also the $\mathrm{CO}$ emission occurs. Carbon monoxide is the product of carbon with sodium or potassium oxides and carbonates (Equations (7) and (8)) [50].

$$
\begin{gathered}
\mathrm{Me}_{2} \mathrm{O}+\mathrm{C} \rightarrow 2 \mathrm{Me}+\mathrm{CO} \\
\mathrm{Me}_{2} \mathrm{CO}_{3}+\mathrm{C} \rightarrow 2 \mathrm{Me}+3 \mathrm{CO}
\end{gathered}
$$

In turn, the release of water vapor is primarily associated with the physical state of the activators used, as well as the physicochemical properties of hydroxides. The course of water release curves is different. In the carbon activation process using $\mathrm{KOH}$, water is released at temperatures from 300 to $500{ }^{\circ} \mathrm{C}$, whereas with the use of $\mathrm{NaOH}$ it is only above $600{ }^{\circ} \mathrm{C}$. It is assumed that metallic hydroxide activators react with carbon, volatile oxidation products or decompose with the release of water (Equations (6), (9) and (10)) [47,50].

$$
\begin{gathered}
4 \mathrm{MeOH}+2 \mathrm{CO}_{2} \rightarrow 2 \mathrm{Me}_{2} \mathrm{CO}_{3}+2 \mathrm{H}_{2} \mathrm{O} \\
2 \mathrm{MeOH} \rightarrow \mathrm{Me}_{2} \mathrm{O}+\mathrm{H}_{2} \mathrm{O}
\end{gathered}
$$

Activation with $\mathrm{NaOH}$ leads to the release of larger volumes of reaction gases at higher temperatures than when activated with $\mathrm{KOH}$. Thus, above $600{ }^{\circ} \mathrm{C}$, Equations (6) and (9), leading to the release of water vapor and carbon dioxide, are more likely for carbon activation with $\mathrm{NaOH}$. Additionally, the emission of hydrogen generated in the reaction of $\mathrm{NaOH}$ with a carbon matrix appears in the reaction space also at temperatures higher than at the application of $\mathrm{KOH}$. This may indicate a lower share of sodium carbonate in activation processes than in the case of potassium carbonate, which is formed at higher temperatures of carbon activation using $\mathrm{KOH}$. At temperatures above $700^{\circ} \mathrm{C}$, the emission of carbon monoxide is evidently more intensive when $\mathrm{NaOH}$ is used $[48,49]$. On this basis, it can be concluded that the formation of acid surface groups is influenced not only by the oxygen content in carbonizate, but also by the amount of oxygen supplied from products of the reaction between an activator and carbon. Having in mind the thermal stability of individual functional groups, it should be stated that lower concentrations of acid groups in carbons obtained after $\mathrm{NaOH}$ activation are associated with more difficult oxidation of the carbon surface than in the case of $\mathrm{KOH}$ activation.

All ACs obtained from miscanthus and switchgrass biomass were characterized by a developed porous structure, as indicated by the high iodine numbers and direct assays (Table 5). As IN is an indicator of microporosity (pores $<1 \mathrm{~nm}$ in diameter), higher INs reflect better development of the microporous structure, on which greater adsorption abilities for low-molar-mass solutes depend to a large extent [51]. This should definitely be a subject of the next phase of research. At this moment, it can be stated that an extensive specific surface area and large pore volume were found for virtually all ACs. However, higher values, especially of $\mathrm{S}_{\mathrm{BET}}, \mathrm{V}_{\text {micro }}$ (both also with the determined significant effect of activator), as well as $\mathrm{V}_{\mathrm{T}}$ and $\mathrm{IN}$, were found for ACs obtained after the use of $\mathrm{NaOH}$. Thus, 
analyses of $\mathrm{AC}$ porosity also confirmed that the mechanism of action for $\mathrm{KOH}$ and $\mathrm{NaOH}$ hydroxides is different.

Structural and surface parameters were similar for all ACs, yet the best were found for $\mathrm{MSac} / \mathrm{NaOH}$ followed by $\mathrm{SG} / \mathrm{NaOH}$, i.e., those obtained by $\mathrm{NaOH}$ activation of carbonizates from $M$. sacchariflorus or switchgrass biomass, respectively (Table 5). It is difficult to comprehensively explain the reason for this fact, especially since the chemical composition of all used biomass feedstocks was similar (Tables 2 and 3). However, certain selected common characteristics of MSac and SG, significantly different from the other feedstocks, may be indicated. These were the above-mentioned intermediate lignin contents and low amounts of ash, which synergistically might have exerted some positive impact on the porous structure of obtained ACs. This possible effect, expanded to cover the lignin subunit composition and ultrastructure, could be a subject of further detailed research. Literature studies also indicate that each natural material requires an individual approach and the mechanism of pyrolysis is specific to a particular raw material. It is related to the diversity in the structure of lignocellulosic biomass, i.e., different chemical composition and diverse anatomical structure [52].

The values of $\mathrm{S}_{\mathrm{BET}}$ and other parameters of porous structure for ACs derived from miscanthus and switchgrass are comparable with those of other lignocellulosic materials obtained using the same activation methods (Table 7). The only exceptions to that rule are clearly higher $\mathrm{S}_{\mathrm{BET}}$ values for ACs produced by $\mathrm{KOH}$ activation from walnut shells and plum stones composed of sclereid cells with strongly lignified and thickened cell walls.

Table 7. Parameters of porous structure of chemically activated carbons derived from different precursors.

\begin{tabular}{|c|c|c|c|c|c|c|c|}
\hline \multirow{2}{*}{ Precursor } & \multirow{2}{*}{$\begin{array}{l}\text { Activation } \\
\text { Agent }\left({ }^{\circ} \mathrm{C}\right)\end{array}$} & \multirow{2}{*}{$\begin{array}{c}\text { Surface Area } \\
\left(\mathrm{m}^{2} / \mathrm{g}\right) \\
\mathrm{S}_{\mathrm{BET}}\end{array}$} & \multicolumn{3}{|c|}{ Pore Volume $\left(\mathrm{cm}^{3} / \mathrm{g}\right)$} & \multirow{2}{*}{$\begin{array}{c}\text { Pore } \\
\text { Diameter } \\
(\mathbf{n m}) \\
\mathbf{d}_{\mathrm{av}}\end{array}$} & \multirow{2}{*}{ Ref. } \\
\hline & & & $\mathbf{V}_{T}$ & $\mathrm{~V}_{\text {micro }}$ & $\mathrm{V}_{\text {meso }}$ & & \\
\hline \multirow{3}{*}{$\begin{array}{l}\text { Walnut } \\
\text { shells } \\
\text { Pistachio } \\
\text { shells }\end{array}$} & KOH/750 & 2041 & 1.12 & 0.33 & 0.79 & 2.19 & \multirow{3}{*}{ [53] } \\
\hline & $\mathrm{NaOH} / 750$ & 1864 & 1.09 & 0.29 & 0.80 & 2.34 & \\
\hline & $\mathrm{NaOH} / 750$ & 1710 & 1.07 & 0.63 & 0.44 & 2.50 & \\
\hline $\begin{array}{l}\text { Peanut } \\
\text { shells }\end{array}$ & $\mathrm{NaOH} / 750$ & 1793 & 1.24 & 0.30 & 0.94 & 2.77 & \multirow{5}{*}{ [54] } \\
\hline $\begin{array}{l}\text { Common } \\
\text { osier stems }\end{array}$ & $\mathrm{KOH} / 750$ & 1810 & 1.11 & 0.31 & 0.80 & 2.45 & \\
\hline $\begin{array}{l}\text { Hemp } \\
\text { stems }\end{array}$ & $\mathrm{KOH} / 750$ & 1625 & 1.08 & 0.53 & 0.55 & 2.66 & \\
\hline \multirow{3}{*}{$\begin{array}{l}\text { Flax stems } \\
\text { Plum } \\
\text { stones } \\
\text { Hornbeam } \\
\text { wood }\end{array}$} & $\mathrm{KOH} / 750$ & 1507 & 1.01 & 0.51 & 0.50 & 2.68 & \\
\hline & $\mathrm{KOH} / 750$ & 2270 & 1.09 & 1.02 & 0.07 & 1.92 & \\
\hline & $\begin{array}{c}\mathrm{KOH} / 950 \\
\mathrm{NaOH} / 950\end{array}$ & $\begin{array}{l}1862 \\
1492\end{array}$ & $\begin{array}{l}1.00 \\
0.98\end{array}$ & $\begin{array}{l}0.79 \\
0.25\end{array}$ & $\begin{array}{l}0.21 \\
0.73\end{array}$ & $\begin{array}{l}2.15 \\
2.61\end{array}$ & [55] \\
\hline
\end{tabular}

The results of TG analysis based on changes in the mass of respective samples at consecutive stages of thermolysis (Table 6) indicate varied thermal properties of the obtained ACs. Depending on the temperature, particular oxygen surface groups decompose. It is assumed that, in the range of $200-500{ }^{\circ} \mathrm{C}$, stronger acidic groups (e.g., carboxyl) are degraded, whereas at $500-700{ }^{\circ} \mathrm{C}$, weakly acidic groups (e.g., phenolic) disintegrate. However, at temperatures above $700{ }^{\circ} \mathrm{C}$, groups of basic characters are broken down [56]. Therefore, the percentage share of functional groups in the AC structure corresponds to the thermal properties of the tested materials.

ACs obtained with the use of $\mathrm{KOH}$ as an activator contained more carboxyl groups of strongly acidic character, as well as a higher number of lactonic groups, which may be broken down and release carboxyl groups (Table 4). In the temperature range associated with the degradation of these groups $\left(200-700{ }^{\circ} \mathrm{C}\right)$, the above-mentioned ACs showed greater mass losses as well as a significant effect of activator in the part of the range (Table 6). As shown above, the use of $\mathrm{NaOH}$ as the activator caused an increase in the number of basic oxygen groups (Table 4), which was also reflected in the 
results of TG analysis. These ACs showed greater mass losses and partially also a significant effect of activator (Table 6) in the temperature range of $700-1200{ }^{\circ} \mathrm{C}$, i.e., specific to the decomposition of basic functional groups. For the tested ACs, mass losses were also determined in the whole range of thermal analysis, i.e., from 20 to $1200{ }^{\circ} \mathrm{C}$. The values of these mass losses may be treated as a measure of the thermal stability of the obtained ACs. However, for particular precursors, the effect of the activators on thermal stability was generally opposite, which further confirms their different activation mechanisms. In addition, for most temperature ranges, ACs obtained by $\mathrm{NaOH}$ activation were slightly more stable. Overall, $\mathrm{MG} / \mathrm{NaOH}, \mathrm{MSin} / \mathrm{NaOH}$ and $\mathrm{MSac} / \mathrm{KOH}$ may be considered the most thermally resistant ACs. Nonetheless, it may be assumed that the above-mentioned ACs with the most developed porous structure, i.e., $\mathrm{SG} / \mathrm{NaOH}$ and especially $\mathrm{MSac} / \mathrm{NaOH}$, have the highest potential applicability, e.g., in decontamination or purification, to replace carbons obtained so far from M. $\times$ giganteus $[9,27]$.

\section{Conclusions}

Tested miscanthus species and switchgrass exhibited a biomass composition typical of the temperate climate and in part to its transitional or even continental subtype. These materials proved to be good feedstocks to produce activated carbons, comparable to traditional biomass sources. All obtained ACs were characterized by a rich chemical structure of the surface, a well-developed porous structure and sufficient thermal stability. The activators, $\mathrm{KOH}$ or $\mathrm{NaOH}$, exerted a stronger effect on the AC surface as well as porosity parameters and thermal stability than biomass composition. Yet, the latter, particularly contents of lignin and mineral compounds, may have some impact on AC properties. This study has shown that the mechanisms of $\mathrm{KOH}$ and $\mathrm{NaOH}$ action on carbon precursors were not identical, which directly affected the structure and properties of carbon materials. Both activators mostly generated the formation of surface acidic functional groups, while it was at to larger extent in the case of $\mathrm{KOH}$. However, more extensive specific surface areas, larger micropore volume, as well as slightly higher iodine numbers of ACs and thermal stability, were obtained when $\mathrm{NaOH}$ was used. This study provides a good basis for detailed studies on the structure and adsorption abilities of ACs obtained from miscanthus and switchgrass, as well as the effect of the composition of biomass harvested at different years and environments on AC properties. Nonetheless, this study has already demonstrated that ACs derived from M. sacchariflorus and to a lesser extent also those derived from switchgrass have surface and porosity parameters with the highest potential practical applicability. Hence, even if these crop species are not abundant effective biomass sources for energy purposes, they may become valuable feedstocks for activated carbons.

Author Contributions: B.D., B.W and J.C.-W. formulated the concept of the study; B.D., M.B. and B.W designed the study; B.D. and M.B. obtained activated carbons and performed their analyses; J.C.-W. prepared plant materials; G.O. performed chemical analysis of plant materials; T.P. performed statistical analysis; B.D., B.W. and T.P interpreted the results; B.D. supervised the whole study; B.D. and B.W wrote the draft of the manuscript; T.P. completed and revised the manuscript. All authors have read and agreed to the published version of the manuscript.

Funding: This study was funded by statutory funds of the Poznań University of Life Sciences, the Institute of Chemical Wood Technology and the Institute of Plant Genetics PAS.

Acknowledgments: The paper publication was financed within the framework of the Ministry of Science and Higher Education program 'Regional Initiative of Excellence' in the years 2019-2022, Project No. 005/RID/2018/19.

Conflicts of Interest: The authors declare no conflicts of interest. 


\section{References}

1. Menéndez-Díaz, J.Á.; Martin-Gullón, I. Types of carbon adsorbents and their production. In J. Activated Carbon Surfaces in Environmental Remediation, 1st ed.; Bandosz, T.J., Ed.; Elsevier Ltd.: Kidlington, Oxford, UK, 2006; Volume 7, pp. 1-47.

2. Mordor Intelligence. Activated Carbon Market—Growth, Trends, and Forecast (2019-2024). Available online: https://www.mordorintelligence.com/industry-reports/activated-carbon-market (accessed on 7 December 2019).

3. Ceskaa. Global Activated Carbon Market: (2014-2019). Available online: www.ceskaa.com/market-report/ advanced-materials/global-activated-carbon-market-2014-2019 (accessed on 26 August 2016).

4. Deliyanni, E.A.; Kyzas, G.K.; Triantafyllidis, K.S.; Matis, K.A. Activated carbons for the removal of heavy metal ions: A systematic review of recent literature focused on lead and arsenic ions. Open Chem. 2015, 13, 699-708. [CrossRef]

5. Hernandez-Montoya, V.; Mendoza-Castillo, D.I.; Bonilla-Petriciolet, A.; Montes-Moran, M.A.; Perez-Cruz, M.A. Role of the pericarp of Carya illinoinensis as biosorbent and as precursor of activated carbon for the removal of lead and acid blue 25 in aqueous solutions. J. Anal. Appl. Pyrolysis 2011, 92, 143-151. [CrossRef]

6. Ash, B.; Satapathy, D.; Mukherejee, P.S.; Nanda, B.; Gumaste, J.L.; Mishra, B.K. Characterization and application of active carbon prepared from waste coir pith. J. Sci. Ind. Res. India 2006, 65, 12-1008.

7. Tao, X.; Xiaoqin, L. Peanut shell activated carbon: Characterization, surface, modification and adsorption of $\mathrm{Pb}^{2+}$ from aqueous solution. Chin. J. Chem. Eng. 2008, 16, 401-406.

8. Peng, X.; Fu, J.; Zhang, C.; Tao, J.; Sun, L.; Chu, P.K. Rice Husk-Derived Activated Carbon for Li Ion Battery Anode. Nanosci. Nanotechnol. Lett. 2014, 6, 68-71. [CrossRef]

9. Li, S.; Bi, X.; Tao, R.; Wang, Q.; Yao, Y.; Wu, F.; Zhang, C. Ultralong Cycle Life Achieved by a Natural Plant: Miscanthus $\times$ giganteus for Lithium Oxygen Batteries. ACS Appl. Mater. Interfaces 2017, 9, 4382-4390. [CrossRef]

10. Cagnon, B.; Py, X.; Guillot, A.; Stoeckli, F.; Chambat, G. Contributions of hemicellulose, cellulose and lignin to the mass and the porous properties of chars and steam activated carbons from various lignocellulosic precursors. Bioresour. Technol. 2009, 100, 292-298. [CrossRef]

11. Yahya, M.A.; Al-Qodah, Z.; Zanariah Ngah, C.W. Agricultural bio-waste materials as potential sustainable precursors used for activated carbon production: A review. Renew. Sustain. Energy Rev. 2015, 46, $218-235$. [CrossRef]

12. Nor, N.M.; Lau, L.C.; Lee, K.T.; Mohamed, A.R. Synthesis of activated carbon from lignocellulosic biomass and its applications in air pollution control: A review. J. Environ. Chem. Eng. 2013, 1, 658-666.

13. Friesen, P.C.; Peixoto, M.M.; Busch, F.A.; Johnson, D.C.; Sage, R.F. Chilling and frost tolerance in Miscanthus and Saccharum genotypes bred for cool temperate climates. J. Exp. Bot. 2014, 65, 3749-3758. [CrossRef]

14. Lowry, D.B.; Behrman, K.D.; Grabowski, P.; Morris, G.P.; Kiniry, J.R.; Juenger, T.E. Adaptations between ecotypes and along environmental gradients in Panicum virgatum. Am. Nat. 2014, 183, 682-692. [CrossRef] [PubMed]

15. Clifton-Brown, J.; Hastings, A.; Mos, M.; McCalmont, J.P.; Ashman, C.; Awty-Carroll, D.; Cerazy, J.; Chiang, Y.-C.; Cosentino, S.; Cracroft-Eley, W.; et al. Progress in upscaling Miscanthus biomass production for the European bio-economy with seed-based hybrids. GCB Bioenergy 2017, 9, 6-17. [CrossRef]

16. Jeżowski, S.; Głowacka, K.; Kaczmarek, Z. Variation on biomass yield and morphological traits of energy grasses from the genus Miscanthus during the first years of crop establishment. Biomass Bioenerg 2011, 35, 814-821. [CrossRef]

17. Cadoux, S.; Ferchaud, F.; Demay, C.; Boizard, H.; Machet, J.-M.; Fourdinier, E.; Preudhomme, M.; Chabbert, B.; Gosse, G.; Mary, B. Implications of productivity and nutrient requirements on greenhouse gas balance of annual and perennial bioenergy crops. GCB Bioenergy 2014, 6, 425-438. [CrossRef]

18. Cherney, J.H.; Cherney, D.J.R.; Paddock, K.M. Biomass yield and composition of switchgrass bales on marginal land as influenced by harvest management scheme. Bioenergy Res. 2018, 11, 33-43. [CrossRef]

19. Cerazy-Waliszewska, J.; Jeżowski, S.; Łysakowski, P.; Waliszewska, B.; Zborowska, M.; Sobańska, K.; Ślusarkiewicz-Jarzina, A.; Białas, W.; Pniewski, T. Potential of bioethanol production from biomass of various Miscanthus genotypes cultivated in three-year plantations in west-central Poland. Ind. Crop. Prod. 2019, 141, 111790. [CrossRef] 
20. Shuai Xue, S.; Lewandowski, I.; Wang, X.; Yi, Z. Assessment of the production potentials of Miscanthus on marginal land in China. Renew. Sustain. Energy Rev. 2016, 54, 932-943.

21. Feng, Q.; Chaubey, I.; Engel, B.; Cibina, R.; Sudheer, K.P.; Volenec, J. Marginal land suitability for switchgrass, Miscanthus and hybrid poplar in the Upper Mississippi River Basin (UMRB). Environ. Model. Softw. 2017, 93, 356-365. [CrossRef]

22. Wagner, M.; Mangold, A.; Lask, J.; Petig, E.; Andreas Kiesel, A.; Lewandowski, I. Economic and environmental performance of miscanthus cultivated on marginal land for biogas production. GCB Bioenergy 2019, 11, $34-49$. [CrossRef]

23. Sigua, G.C.; Novak, J.M.; Watts, D.W.; Szögi, A.A.; Shumaker, P.D. Impact of switchgrass biochars with supplemental nitrogen on carbon-nitrogen mineralization in highly weathered Coastal Plain Ultisols. Chemosphere 2016, 145, 135-141. [CrossRef]

24. Janus, A.; Pelfrêne, A.; Sahmer, K.; Heymans, S.; Deboffe, C.; Douay, F.; Waterlot, C. Value of biochars from Miscanthus $\times$ giganteus cultivated on contaminated soils to decrease the availability of metals in multicontaminated aqueous solutions. Environ. Sci. Pollut. Res. Int. 2017, 24, 18204-18217. [CrossRef] [PubMed]

25. Khan, W.-U.-D.; Ramzani, P.M.A.; Anjum, S.; Abbas, F.; Iqbal, M.; Yasar, A.; Ihsan, M.Z.; Anwar, M.N.; Baqar, M.; Tauqeer, H.M.; et al. Potential of miscanthus biochar to improve sandy soil health, in situ nickel immobilization in soil and nutritional quality of spinach. Chemosphere 2017, 185, 1144-1156. [CrossRef] [PubMed]

26. Novak, J.M.; Ippolito, J.A.; Ducey, T.F.; Watts, D.W.; Spokas, K.A.; Trippe, K.M.; Sigua, G.C.; Johnson, M.G. Remediation of an acidic mine spoil: Miscanthus biochar and lime amendment affects metal availability, plant growth, and soil enzyme activity. Chemosphere 2018, 205, 709-718. [CrossRef] [PubMed]

27. Anstey, A.; Vivekanandhan, S.; Rodriguez-Uribe, A.; Misra, M.; Mohanty, A.K. Oxidative acid treatment and characterization of new biocarbon from sustainable Miscanthus biomass. Sci. Total Environ. 2016, 550, 241-247. [CrossRef]

28. Lorenc, H. Climatic Atlas of Poland. Institute of Meteorology and Water Management; National Research Institute: Warszawa, Poland, 2005; (In Polish and In English).

29. Seifert, K. Zur Frage der Cellulose-Schnellbestimmung nach der Acetylacetone-Methode. Das Papier 1960, 14, 104-106. (in German).

30. Boehm, H.P. Surface oxides on carbon and their analysis: A critical assessment. Carbon 2002, 40, 145-149. [CrossRef]

31. Prosiński, S. Chemia Drewna, wyd. 2; PWRiL: Warszawa, Poland, 1984; pp. 1-475, (Wood Chemistry, In Polish).

32. Brosse, N.; Dufour, A.; Meng, X.; Sun, Q.; Ragauskas, A. Miscanthus: A fast-growing crop for biofuels and chemicals production. Biofuels Bioprod. Biorefin. 2012, 6, 580-598. [CrossRef]

33. Lee, W.-C.; Kuan, W.-C. Miscanthus as cellulosic biomass for bioethanol production. Biotechnol. J. 2015, 10, 840-854. [CrossRef]

34. Butkutè, B.; Lemežienè, N.; Cesevičienè, J.; Liatukas, Ž.; Dabkevičienè, G. Carbohydrate and lignin partitioning in switchgrass (Panicum virgatum L.) biomass as a bioenergy feedstock. Zemdirb. Agric. 2013, 100, 251-260. [CrossRef]

35. Aboytes-Ojeda, M.; Castillo-Villar, K.K.; Yu, T.E.; Boyer, C.N.; English, B.C.; Larson, J.A.; Kline, L.M.; Labbé, N. A principal component analysis in switchgrass chemical composition. Energies 2016, 9, 913. [CrossRef]

36. Allison, G.G.; Morris, C.; Clifton-Brown, J.; Lister, S.J.; Donnison, I.S. Genotypic variation in cell wall composition in a diverse set of 244 accessions of Miscanthus. Biomass Bioenergy 2011, 35, 4740-4747. [CrossRef]

37. Hodgson, E.M.; Nowakowski, D.J.; Shield, I.; Riche, A.; Bridgwater, A.V.; Clifton-Brown, J.C.; Donnison, I.S. Variation in Miscanthus chemical composition and implications for conversion by pyrolysis and thermo-chemical bio-refining for fuels and chemicals. Bioresour. Technol. 2011, 102, 3411-3418. [CrossRef] [PubMed]

38. Gismatulina, Y.A.; Budaeva, V.V. Chemical composition of five Miscanthus sinensis harvests and nitric-acid cellulose therefrom. Ind. Crop. Prod. 2017, 109, 227-232. [CrossRef]

39. Gismatulina, Y.A.; Budaeva, V.V.; Veprev, S.G.; Sakovich, G.V.; Shumny, V.K. Cellulose from Various Parts of Soranovskii Miscanthus. Russ. J. Genet. Appl. Res. 2015, 5, 60-68. [CrossRef] 
40. Arnoult, S.; Obeuf, A.; Béthencourt, L.; Mansard, M.-C.; Brancourt-Hulmel, M. Miscanthus clones for cellulosic bioethanol production: Relationships between biomass production, biomass production components, and biomass chemical composition. Ind. Crop. Prod. 2015, 63, 316-328. [CrossRef]

41. Waliszewska, B.; Janyszek, M.; Grzelak, M.; Gaweł, E. Characteristic of thermochemical parameters of aboveground parts of selected sedges (Carex L. Cyperaceae). IOSR J. Agric. Vet. Sci. 2013, 5, 1-6. [CrossRef]

42. Boakye-Boaten, N.A.; Xiu, S.; Shahbazi, A.; Wang, L.; Rui, L.; Mims, M.; Schimmel, K. Effects of fertilizer application and dry/wet processing of Miscanthus $\times$ giganteus on bioethanol production. Bioresour. Technol. 2016, 204, 98-105. [CrossRef]

43. Lewandowski, I.; Clifton-Brown, J.C.; Andersson, B.; Basch, G.; Christian, D.G.; Jørgensen, U.; Jones, M.B.; Riche, A.B.; Schwarz, K.U.; Tayebi, K.; et al. Environment and harvest time affects the combustion qualities of Miscanthus genotypes. Agron. J. 2003, 95, 1274-1280. [CrossRef]

44. Dubis, B.; Bułkowska, K.; Lewandowska, M.; Szempliński, W.; Jankowski, K.J.; Idźkowski, J.; Kordala, N.; Szymańska, K. Effect of different nitrogen fertilizer treatments on the conversion of Miscanthus $\times$ giganteus to ethanol. Bioresour. Technol. 2017, 243, 731-737. [CrossRef]

45. Lozano-Castelló, D.; Lillo-Ródenas, M.A.; Cazorla-Amorós, D.; Linares-Solano, A. Preparation of activated carbons from Spanish anthracite. Part I. Activation by KOH. Carbon 2001, 39, 741-749. [CrossRef]

46. Lozano-Castelló, D.; Lillo-Ródenas, M.A.; Cazorla-Amorós, D.; Linares-Solano, A. Preparation of activated carbons from Spanish anthracite. Part II. Activation by NaOH. Carbon 2001, 39, 751-759. [CrossRef]

47. Lillo-Ródenas, M.A.; Cazorla-Amorós, D.; Linares-Solano, A. Understanding chemical reactions between carbons and $\mathrm{NaOH}$ and $\mathrm{KOH}$. An insight into the chemical activation mechanism. Carbon 2003, 41, $267-275$. [CrossRef]

48. Lillo-Ródenas, M.A.; Juan-Juan, J.; Cazorla-Amorós, D.; Linares-Solano, A. About reactions occurring during chemical activation with hydroxides. Carbon 2004, 42, 1371-1375. [CrossRef]

49. Lillo-Ródenas, M.A.; Marco-Lozar, J.P.; Cazorla-Amorós, D.; Linares-Solano, A. Activated carbons prepared by pyrolysis of mixtures of carbon precursor/alkaline hydroxide. J. Anal. Appl. Pyrolysis 2007, 80, 166-174. [CrossRef]

50. Alcaniz-Monge, J.; Illan-Gomez, M.J. Insight into hydroxides activated coals: Chemical or physical activation? J. Colloid Interface Sci. 2008, 318, 35-41. [CrossRef]

51. Azis, A.; Ouali, M.S.; Elandaloussi, E.H.; De Menorval, L.C.; Lindheimer, M. Chemically modified olive stone: A low cost-sorbent for heavy metals and basic dyes removal from aqueous solution. J. Hazard. Mater. 2009, 163, 441-447. [CrossRef]

52. Azevedo, D.C.S.; Araújo, J.C.S.; Bastos-Neto, M.; Torres, A.E.B.; Jaguaribe, E.F.; Cavalcante, C.L. Microporous activated carbon prepared from coconut shells using chemical activation with zinc chloride. Microporous Mesoporous Mater. 2007, 100, 361-364. [CrossRef]

53. Doczekalska, B.; Marcinkowski, M.; Bartkowiak, B.; Katolik, Z. The study of physicochemical properties of activated carbons obtained from nut shells. Ann. Wars. Univ. Life Sci. SGGW 2018, 104, 75-79.

54. Doczekalska, B.; Bartkowiak, M.; Orszulak, G.; Katolik, Z. Porous structure of activated carbon from biomass. Ann. Wars. Univ. Life Sci. SGGW 2017, 99, 113-116.

55. Doczekalska, B.; Pawlicka, A.; Kuśmierek, K.; Światkowski, A.; Bartkowiak, M. Adsorption of 4-chlorophenol from aqueous solution on activated carbons derived from hornbeam wood. Wood Res. 2017, 62, 261-272.

56. Świątkowski, A.; Siemieniewska, T.; Dąbek, L. Adsorpcja na Węglu Aktywnym, wyd. 1; WNT: Warszawa, Poland, 2009; pp. 1-480, (In Polish). Polish translation from English: Bansal, R.C., Goyal, M. Activated Carbon Adsorption, 1st ed.; CRC Press: New York, NY USA, 2005.

(C) 2020 by the authors. Licensee MDPI, Basel, Switzerland. This article is an open access article distributed under the terms and conditions of the Creative Commons Attribution (CC BY) license (http://creativecommons.org/licenses/by/4.0/). 